\title{
Interleukin 1 Induces Prolonged L-Arginine-dependent Cyclic Guanosine Monophosphate and Nitrite Production in Rat Vascular Smooth Muscle Cells
}

\author{
Debbie Beasley, John H. Schwartz, ${ }^{\star}$ and Barry M. Brenner \\ Renal Divisions, Brigham and Women's Hospital, Harvard Medical School, Boston, Massachusetts 02115; and Thorndike
}

Memorial Laboratory, ${ }^{*}$ Boston City Hospital, Boston University Medical Center, ${ }^{*}$ Boston, Massachusetts 02118

\begin{abstract}
The cytokine interleukin 1 (IL-1) inhibits contractile responses in rat aorta by causing endothelium-independent and prolonged activation of soluble guanylate cyclase. The present study tested whether IL-1 activates guanylate cyclase by inducing prolonged production of nitric oxide in cultured rat aortic vascular smooth muscle cells (VSMC). IL-1 induced a marked timedependent increase in cyclic guanosine monophosphate (cGMP) in VSMC which was significant at $6 \mathrm{~h}$, and increased progressively for up to $36 \mathrm{~h}$. This effect of IL-1 was abolished when protein synthesis was inhibited with cycloheximide or actinomycin D, suggesting that the effect of IL-1 involves new protein synthesis. IL-1-induced cGMPaccumulation was inhibited by the soluble guanylate cyclase inhibitors, methylene blue, LY83583, and hemoglobin and by the $L$-arginine analogue $\mathbf{N}^{\mathbf{G}}$ monomethyl-L-arginine (L-NMMA). The inhibitory effect of L-NMMA was reversed by a 10-fold excess of $L$-arginine, but not by D-arginine. Nitrite, an oxidation product of nitric oxide, accumulated in the media of VSMC incubated with IL-1 for $24 \mathrm{~h}$ in the presence of L-arginine, whereas both IL-1-induced cGMP accumulation and nitrite production were attenuated in VSMC incubated in L-arginine-deficient medium. In L-arginine-depleted VSMC, IL-1-induced cGMP accumulation was restored to control levels by a 15-min incubation with L-arginine. These results demonstrate that IL-1 activates guanylate cyclase in rat VSMC by inducing production of nitric oxide via a pathway dependent on extracellular $L$-arginine. ( $J$. Clin. Invest. 1991. 87:602-608.) Key words: cyclic guanosine monophosphate $\cdot$ guanylate cyclase $\bullet \mathbf{N}^{\mathbf{G}}$ monomethyl-L-arginine $\bullet$ nitric oxide
\end{abstract}

\section{Introduction}

Vasodilatation is a major feature of infection and inflammation, both systemically during sepsis, and locally in response to local infection and inflammation. The monocyte- and macrophage-derived cytokine interleukin 1 (IL-1), believed to be a major inflammatory mediator, has vasodilatory effects which

Portions of this study were presented at the 74th Annual Meeting of the Federation of American Societies for Experimental Biology (FASEB) and have been published in abstract form (1990. FASEB J. 4:A685).

Address reprint requests to Dr. Beasley, Renal Division, Brigham and Women's Hospital, 221 Longwood Ave., Boston, MA 02115.

Received for publication 12 April 1990 and in revised form 19 September 1990.

J. Clin. Invest.

(c) The American Society for Clinical Investigation, Inc. 0021-9738/91/02/0602/07 \$2.00

Volume 87, February 1991, 602-608 may contribute to inflammatory and septic vasodilatation. In contrast to many vasodilators that act rapidly and via the endothelium, IL- 1 inhibits contraction of rat aortic rings by an endothelium-independent mechanism which involves a lag period of several hours $(1,2)$ and is dependent on protein synthesis (1). However, the vasodilatory effect of IL-1 is similar to the action of endothelium-dependent vasodilators in that it is mediated by activation of soluble guanylate cyclase and production of cyclic guanosine $3^{\prime}, 5^{\prime}$-monophosphate (cGMP [2]).

Endothelium-dependent vasodilators activate soluble guanylate cyclase by causing the release of an endotheliumderived relaxing factor (EDRF [3]), which has recently been identified as nitric oxide $(4,5)$. Endothelial cells that have been activated by endothelium-dependent vasodilators produce nitric oxide by enzymatic oxidation of the guanidino nitrogen of L-arginine (5-8). Since activation by cytokines has recently been shown to stimulate a similar pathway of nitric oxide production in macrophages (9-11), we hypothesized that the IL-1induced increase in cGMP in rat aortic rings may be mediated by activation of nitric oxide production from $\mathrm{L}$-arginine in vascular smooth muscle cells (VSMC [2]). ${ }^{1}$

In the present study we report that IL-1 induces a similar delayed increase in cGMP in VSMC cultured from rat aorta. IL-1-induced cGMP accumulation is associated with production of nitrite, an oxidation product of nitric oxide, and both cGMP and nitrite production are dependent on an extracellular source of $\mathrm{L}$-arginine. These results indicate that IL-1 activates soluble guanylate cyclase by inducing nitric oxide production in VSMC.

\section{Methods}

Culture of VSMC. VSMC were isolated from rat aorta by enzymatic dissociation using standard methods $(12,13)$. Briefly, aorta were removed aseptically and placed in Hanks' balanced salt solution (HBSS), and the endothelium and adventitia were removed. Each aorta was cut into rings and incubated for $90 \mathrm{~min}$ at $37^{\circ} \mathrm{C}$ in HBSS containing 0.2 $\mathrm{mM} \mathrm{CaCl}_{2}, 15 \mathrm{mM}$ Hepes, $1 \mathrm{mg} / \mathrm{ml}$ collagenase (type II, Worthington Biochemical Corp., Freehold, NJ), $0.125 \mathrm{mg} / \mathrm{ml}$ elastase (type III, Sigma Chemical Co., St. Louis, MO), $0.375 \mathrm{mg} / \mathrm{ml}$ soybean trypsin inhibitor (Gibco Laboratories, Grand Island, NY) and $2 \mathrm{mg} / \mathrm{ml}$ bovine serum albumin (Sigma Chemical Co.). The digested tissue was titurated 10 times through a 16-gauge needle and sieved through a $180-\mu \mathrm{m}$ mesh, and the resulting cell suspension was centrifuged at $200 \mathrm{~g}$ for 5 min. The cells were resuspended in Dulbecco's modified Eagle's medium (DME) containing $20 \%$ fetal calf serum and antibiotics, and seeded into $25-\mathrm{cm}^{2}$ flasks $\left(\sim 2 \times 10^{5}\right.$ cells per flask). Cells were passaged once a week by harvesting with trypsin-EDTA and seeding at a 1:5 ratio into 24-well plates. For experiments, cells were grown in DME

1. Abbreviations used in this paper: IBMX, isobutylmethylxanthine; L-NMMA, $\mathbf{N}^{G}$ monomethyl-L-arginine; SNP, sodium nitroprusside; VSMC, vascular smooth muscle cell(s). 
supplemented with $10 \%$ fetal calf serum, glutamine, and antibiotics and were used between passages 5 and 18 after reaching confluence at 4-7 d. The cells were positively identified as smooth muscle by indirect immunofluorescent staining for $\alpha$-actin, using mouse anti- $\alpha$-actin antibody and anti-mouse IgG FITC conjugate (Sigma Chemical Co.). To test for the presence of endothelial cells or macrophages, VSMC cultures were screened for uptake of acetylated low-density lipoprotein (LDL), a modified form of LDL which is internalized by a scavenger pathway in both macrophages (14) and endothelial cells (15). VSMC were incubated with $10 \mu \mathrm{g} / \mathrm{ml}$ acetylated LDL labeled with 1,1'-dioctadecyl-3,3,3',3'-tetramethyl-indo-carbocyanine perchlorate (DiI-AcLDL; Biomedical Technologies, Inc., Stoughton, MA) for $4 \mathrm{~h}$ at $37^{\circ} \mathrm{C}$, and cultures were examined by fluorescence microscopy. VSMC showed no uptake of Dil-Ac-LDL, whereas bovine aortic endothelial cells, studied as a positive control, showed prominent uptake of the label.

Cyclic GMP accumulation in IL-1-treated VSMC. Cell monolayers were washed with HBSS and the medium replaced with $0.5 \mathrm{ml}$ of DME containing 5\% FCS and antibiotics (DME-5), and either (a) no additions, $(b)$ human recombinant IL- $1 \beta(20 \mathrm{ng} / \mathrm{ml}),(c)$ a phosphodiesterase inhibitor, isobutylmethylxanthine (IBMX; $0.1 \mathrm{mM}$ ), or (d) IL-1 and IBMX. After $24 \mathrm{~h}$, cell extracts were obtained for cGMP determination.

To determine the time course of IL-1 action, VSMC were incubated in DME-5 containing IL- $1(20 \mathrm{ng} / \mathrm{ml})$ and CGMP determined at $0,3,6$, $12,18,24,36$, and $48 \mathrm{~h}$, with IBMX $(0.1 \mathrm{mM})$ added to the well $30 \mathrm{~min}$ before obtaining cell extracts.

To determine the effect of protein synthesis inhibition on IL-1-induced cGMP accumulation, VSMC were incubated for $24 \mathrm{~h}$ in DME-5 with or without IL-1 $(20 \mathrm{ng} / \mathrm{ml})$, and in the presence of absence of a protein synthesis inhibitor, cycloheximide $(20 \mu \mathrm{g} / \mathrm{ml})$ or actinomycin $\mathrm{D}(2 \mu \mathrm{g} / \mathrm{ml})$. IBMX $(0.1 \mathrm{mM})$ was added $30 \mathrm{~min}$ before obtaining cell extracts, and sodium nitroprusside (SNP; $10^{-4} \mathrm{M}$ ) was added to some of the control wells in each group $5 \mathrm{~min}$ before extraction of cells for cGMP determination.

Effect of soluble guanylate cyclase inhibitors on IL-1-induced cGMP accumulation. VSMC were incubated for $24 \mathrm{~h}$ in DME-5 with or without IL-1 $(20 \mathrm{ng} / \mathrm{ml})$. $20 \mathrm{~min}$ before the end of the incubation period, IBMX $(0.1 \mathrm{mM})$ and one of the following was added to each well: (a) no additions, (b) LY83583 $\left(10^{-5} \mathrm{M}\right)$, (c) methylene blue $\left(10^{-5} \mathrm{M}\right)$ or $(d)$ human hemoglobin $\left(10^{-5} \mathrm{M}\right)$. SNP $\left(10^{-4} \mathrm{M}\right)$ was added to some of the control wells in each group $5 \mathrm{~min}$ before extraction of cells for cGMP determination.

Role of L-arginine in IL-1-induced CGMP accumulation. VSMC were incubated for $23.5 \mathrm{~h}$ with or without IL-1, in DME-5 (L-arginine concentration is $400 \mu \mathrm{M}$ ). The cells were then washed and the media were replaced with Earle's BSS (L-arginine free). The BSS contained IBMX $(0.1 \mathrm{mM})$ and either $(a)$ no additions, $(b) \mathrm{N}^{G}$ monomethyl-L-arginine ( $30 \mu \mathrm{M}$; L-NMMA), (c) L-NMMA and L-arginine $(300 \mu \mathrm{M})$, or (d) L-NMMA and L-arginine $(300 \mu \mathrm{M})$. After $25 \mathrm{~min}, \mathrm{SNP}\left(10^{-4} \mathrm{M}\right)$ was added to some of the control wells, and after $30 \mathrm{~min}$ cells were extracted for cGMP determination.

Effect of IL-1 on nitrite release from VSMC. The effect of IL-1 on nitrite release from VSMC was determined in cells cultured in the presence or absence of $\mathrm{L}$-arginine. VSMC were incubated for $24 \mathrm{~h}$ with or without IL-1 $(20 \mathrm{ng} / \mathrm{ml})$. The media for these experiments was complete minimum essential medium (MEM with L-arg [600 $\mu \mathrm{M}$ ]; SelectAmine kit, Gibco Laboratories), or MEM without L-arginine. The MEM was supplemented with antibiotics and $5 \%$ dialyzed FCS which was dialyzed for $24 \mathrm{~h}$ against phosphate-buffered saline using 12,000 -mol wt cutoff tubing in order to deplete L-arginine and other amino acids that are present in serum. IBMX $(0.1 \mathrm{mM})$ was added 30 min before obtaining cell extracts for cGMP determination and cell supernatants for nitrite analysis. L-arginine $(600 \mu \mathrm{M})$ was replenished in the supernatant of some of the VSMC incubated with IL-1 in the absence of L-arginine, 15 min before CGMP determinations.

Effect of 4- $h$ L-arginine depletion on IL-1-induced cGMP accumulation. VSMC were incubated for $20 \mathrm{~h}$ in DME-5 with or without IL-1 as described above. The cells were then washed and the DME-5 replaced with MEM with or without L-arginine, which also contained IBMX $(0.1 \mathrm{mM})$ with or without IL-1 $(20 \mathrm{ng} / \mathrm{ml})$. Cyclic GMP content was determined after an additional 4-h incubation, with some of the control cells treated with SNP 5 min before obtaining cell extracts for cGMP determination.

Cyclic GMP measurements. Cyclic GMP was extracted from the cells by rapid aspiration of the medium and addition of $1.0 \mathrm{ml} 0.1 \mathrm{~N}$ $\mathrm{HCl}$ to each well. Cells were incubated with the $\mathrm{HCl}$ for $30 \mathrm{~min}$ at $37^{\circ} \mathrm{C}$ and the extract was frozen at $-20^{\circ} \mathrm{C}$ before assay for cGMP. Protein was extracted from the cells by addition of $0.2 \mathrm{ml} 1 \mathrm{~N} \mathrm{NaOH}$ to each well followed by a 30 -min incubation at $37^{\circ} \mathrm{C}$.

The cGMP content of cell extracts was determined by radioimmunoassay after acetylation, using a rabbit antiserum and ${ }^{125} \mathrm{I}-\mathrm{CGMP}$ obtained from Biomedical Technologies, Inc. Cyclic GMP content was normalized to protein content of each well, which was determined by dye-binding assay (Bio-Rad Laboratories, Richmond, CA) with bovine serum albumin used as a standard.

Nitrite assay. Nitrite was measured by a standard method (16). Aliquots of cell supernatant were mixed with an equal volume of Greiss reagent (prepared by adding 1 part $0.1 \%$ napthylethylenediamine dihydrochloride to 1 part $1 \%$ sulfanilamide in 5\% phosphoric acid) and incubated at room temperature for $10 \mathrm{~min}$. The absorbance at $550 \mathrm{~nm}$ was measured, and nitrite concentration was determined using sodium nitrite as a standard and distilled water as a blank. The background nitrite values of each media were determined and subtracted from experimental values.

Drugs. Human recombinant IL-1- $\beta$ was a gift of Dr. Charles Dinarello, Tufts University, Boston, MA. LY83583 (6-anilino-5,8-quinoline dione) was a gift of Eli Lilly \& Co., Indianapolis, IN. Human hemoglobin was a gift of Dr. R. M. Condi, University of Minnesota, Minneapolis, and was prepared and assayed as previously described (17). This preparation contained $99.4 \%$ oxyhemoglobin and $0.6 \%$ methemoglobin. L-NMMA p-hydroxyazobenzene-p'-sulfonate salt was obtained from Calbiochem-Behring Corp., San Diego, CA. Phenylephrine, methylene blue and SNP were obtained from Sigma Chemical Co.

Data analysis. Significant differences were determined by paired $t$ test, and $P<0.05$ was considered statistically significant.

\section{Results}

IL-1 increases cGMP in rat VSMC. The cGMP content of VSMC incubated with IL-1 $(20 \mathrm{ng} / \mathrm{ml})$ for $24 \mathrm{~h}$ in the absence of the phosphodiesterase inhibitor IBMX, was two times the content of control cells (Fig. $1 ; P<0.05$ ). In the presence of IBMX, exposure to IL- 1 for $24 \mathrm{~h}$ caused cGMP to increase to nine times control cGMP content $(P<0.02)$. In subsequent studies, VSMC cGMP levels were determined in the presence of IBMX, in order to optimize conditions for studying changes in $\mathrm{IL}-1$ responses.

Time course studies indicated that the action of IL-1 is time dependent (Fig. 2), occurring after a delay period of several hours. Cyclic GMP was significantly increased after $6 \mathrm{~h}$ of exposure to IL-1 $(P<0.002)$ and continued to increase, reaching maximal levels at $36 \mathrm{~h}$ of exposure. Cyclic GMP had begun to decrease towards control after $48 \mathrm{~h}$ of incubation.

Treatment of VSMC with the protein synthesis inhibitors, cycloheximide or actinomycin D, blocked IL-1-induced cGMP accumulation (Fig. 3). In contrast, neither cycloheximide nor actinomycin D inhibited the increase in cGMP caused by sodium nitroprusside (data not shown).

Soluble guanylate cyclase inhibitors reverse $I L-1-$ induced cGMP accumulation. The guanylate cyclase inhibitors methylene blue, LY83583, and hemoglobin each attenuated IL-1-in- 

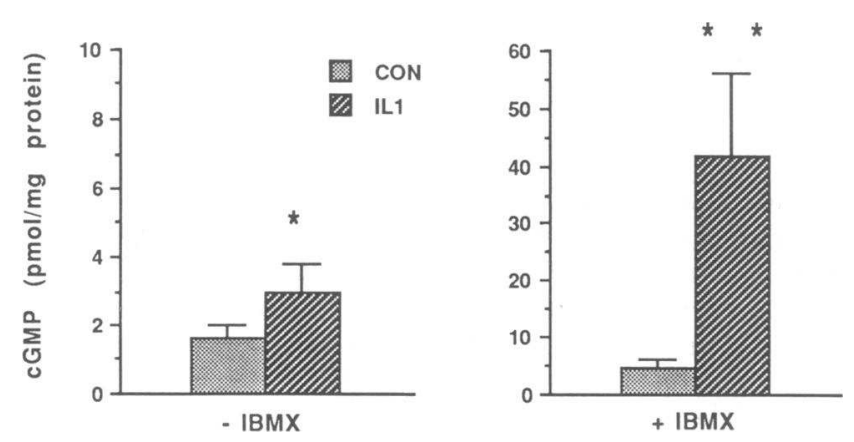

Figure 1. Effect of IL-1 on CGMP content of rat VSMC. VSMC were incubated for $24 \mathrm{~h}$ in DME-5 with or without IL-1 $(20 \mathrm{ng} / \mathrm{ml})$ and in the presence or absence of IBMX $(0.1 \mathrm{mM})$ as indicated. Values shown are mean $\pm \mathrm{SE}$ of 11-14 cultures from four or five experiments. Significantly different from control values: ${ }^{*} P<0.05,{ }^{* *} P<0.02$. CON, control.

duced cGMP accumulation (Fig. 4). Whereas neither inhibitor affected cGMP content in control cells, all three inhibitors markedly decreased cGMP content in IL-1-treated VSMC. Cyclic GMP was increased 18-fold over control values in IL-1treated VSMC in the absence of any inhibitor $(P<0.001)$. The cGMP content of IL-1-treated cells was significantly decreased $(P<0.01)$ in the presence of either LY83583 $\left(10^{-5} \mathrm{M}\right)$, methylene blue $\left(10^{-5} \mathrm{M}\right)$, or hemoglobin $\left(10^{-5} \mathrm{M}\right)$. All three inhibitors attenuated the increase in cGMP caused by sodium nitroprusside $(P<0.05)$ to a similar degree.

L-NMMA attenuates $I L-1$-induced cGMP accumulation. A 30-min incubation with the L-arginine analogue L-NMMA (30 $\mu \mathrm{M})$ attenuated the increased cGMP accumulation in IL-1treated cells (Fig. 5). Cyclic GMP content was increased 13-fold in IL-1-treated VSMC, which were incubated in L-argininefree BSS for $30 \mathrm{~min}(P<0.01)$. This IL-1-induced increase was significantly attenuated $(P<0.025)$ when the VSMC were incubated $30 \mathrm{~min}$ in BSS containing L-NMMA $(30 \mu \mathrm{M})$. The inhibitory effect of L-NMMA was blocked by an excess of L-arginine $(300 \mu \mathrm{M})$. However, in the presence of an excess of D-arginine $(300 \mu \mathrm{M})$ the inhibitory effect of L-NMMA remained $(P$ $<0.025)$. Neither L-NMMA alone nor L-NMMA combined

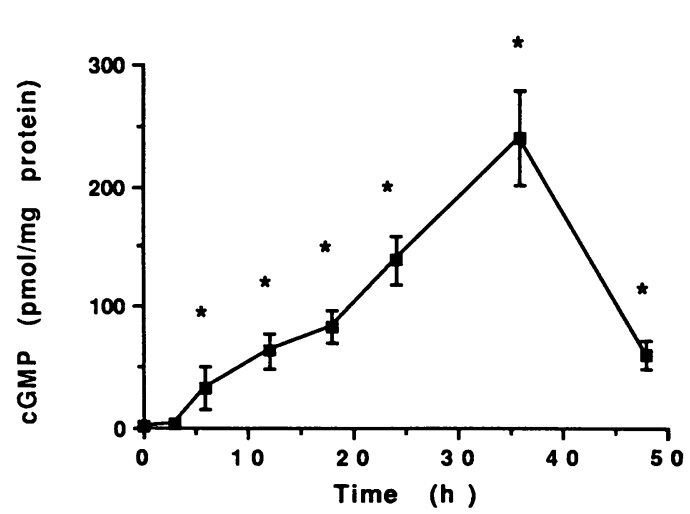

Figure 2. Time course of IL-1-induced cGMP accumulation. VSMC were washed with BSS and the media replaced with DME-5 and IL-1 $(20 \mathrm{ng} / \mathrm{ml})$. Cyclic GMP was then determined at different times as indicated, $30 \mathrm{~min}$ after addition of IBMX $(0.1 \mathrm{mM})$. Values shown are mean $\pm \mathrm{SD}$ of six replicate determinations. ${ }^{*} P<0.002$ significantly different from $0 \mathrm{~h}$.

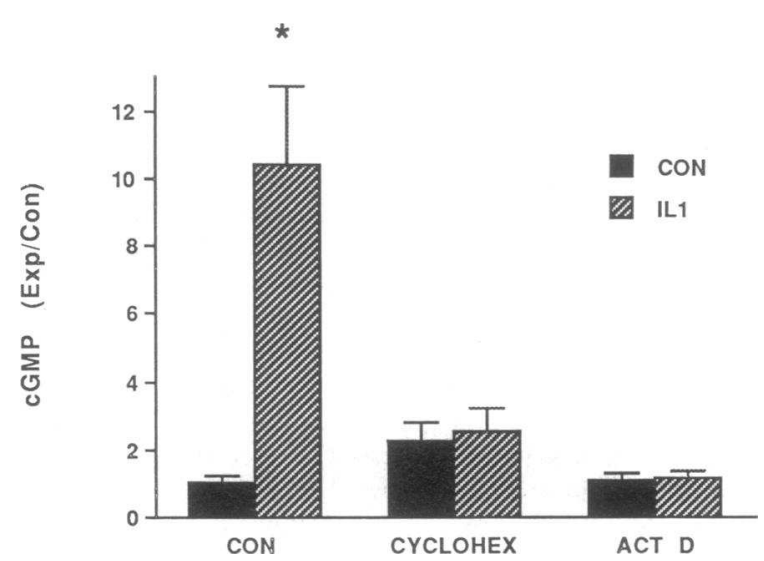

Figure 3. Effect of protein synthesis inhibitors on IL-1-induced cGMP accumulation. VSMC were incubated for $24 \mathrm{~h}$ in DME-5 with or without IL-1 $(20 \mathrm{ng} / \mathrm{ml})$, and in the presence or absence of cycloheximide $(20 \mu \mathrm{g} / \mathrm{ml})$ or actinomycin D $(2 \mu \mathrm{g} / \mathrm{ml})$. IBMX $(0.1$ $\mathrm{mM}$ ) was added to each of the wells $30 \mathrm{~min}$ before cGMP determinations. Values shown are mean \pm SE of 6-10 cultures from two (actinomycin D) or four (cycloheximide) experiments. For each experiment, cGMP values were normalized to the cGMP content of VSMC incubated without IL-1 or protein synthesis inhibitors. ${ }^{*} P$ $<0.005$, significantly different from control. CON, control.

with L- or D-arginine affected the cGMP content of VSMC treated with sodium nitroprusside.

IL-1-treated VSMC release nitrite in L-arginine-replete medium. IL-1 stimulated nitrite accumulation in the media of VSMC cultured for $24 \mathrm{~h}$ in complete MEM containing L-arginine (Fig. 6; $P<0.001$ ). The nitrite concentrations of control and IL-1-treated VSMC supernatants were $0.9 \pm 0.1$ and $31.5 \pm 6.8 \mu \mathrm{M}$, respectively. In contrast, both extracellular nitrite accumulation and intracellular cGMP accumulation were significantly attenuated in IL-1-treated VSMC which were incubated in the absence of $\mathrm{L}$-arginine $(P<0.001)$. L-Arginine depletion did not attenuate SNP-induced increases in cGMP (Fig. 6). In VSMC incubated with IL-1 for $24 \mathrm{~h}$ in the absence of $\mathrm{L}$-arginine, repletion of $\mathrm{L}$-arginine $(600 \mu \mathrm{M}) 15 \mathrm{~min}$ before cGMP determinations restored cGMP accumulation to control levels (Fig. 7).

Short-term L-arginine depletion attenuates $I L-1$-induced cGMP accumulation. Incubation in L-arginine-free MEM for the final $4 \mathrm{~h}$ of a $24-\mathrm{h}$ incubation with IL-1 significantly attenuated, but did not completely reverse, the effect of IL-1 on cGMP (Fig. 8). Cyclic GMP was increased 17-fold in IL-1treated VSMC which were incubated in MEM with L-arginine $(P<0.0025)$. Cyclic GMP was increased sixfold in IL-1treated VSMC which were incubated in MEM without L-arginine $(P<0.01)$, which was significantly less than in the presence of $\mathrm{L}$-arginine $(P<0.0025)$. Incubation in MEM without $\mathrm{L}$-arginine for $4 \mathrm{~h}$ did not affect the increase in cGMP caused by SNP.

\section{Discussion}

These studies demonstrate that IL-1 markedly increases intracellular cGMP in rat aortic VSMC, by a mechanism which is protein synthesis-dependent and involves induction of nitric oxide production. The effect of IL-1 is markedly augmented by the phosphodiesterase inhibitor, IBMX: treatment of VSMC 


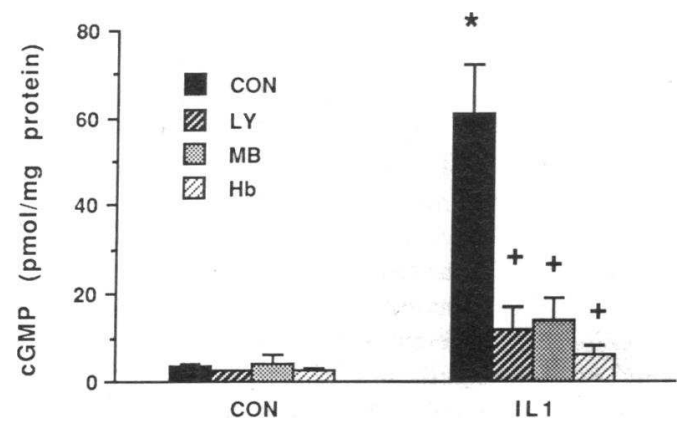

with IL-1 alone for $24 \mathrm{~h}$ caused intracellular cGMP content to increase twofold, whereas cGMP content increased eightfold in VSMC incubated with IL-1 in the presence of IBMX. These results suggest that IL-1 activates guanylate cyclase rather than inhibiting phosphodiesterase.

Cyclic GMP increased in IL-1-treated VSMC after a lag period of $>3 \mathrm{~h}$, and continued to increase until maximal after $\sim 36 \mathrm{~h}$ of exposure to IL-1. This effect of IL-1 was absent in VSMC which were treated with either cycloheximide or actinomycin D, inhibitors of protein translation and RNA transcription, respectively. The delayed action of IL-1, and the absence of IL-1 responses in VSMC in which protein synthesis is inhibited, suggest a mechanism involving new protein synthesis.

Endothelium-dependent vasodilators are known activators of soluble guanylate cyclase that act by causing the rapid and transient release of nitric oxide $(5,6)$, or nitric oxide containing compound (18), from endothelial cells. Studies with inhibitors of endothelium-dependent relaxation, LY83583 (19), methy-

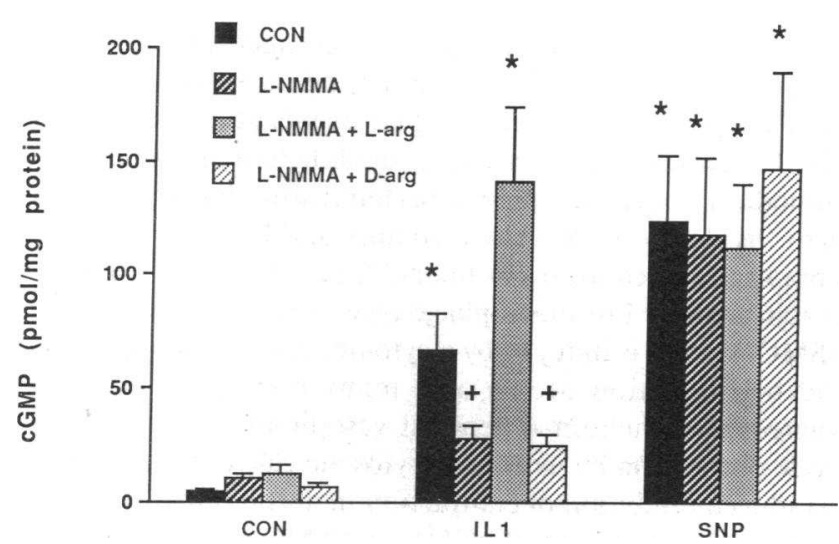

Figure 5. Effect of L-NMMA on IL-1-induced CGMP accumulation in rat VSMC. VSMC were incubated for $24 \mathrm{~h}$ in DME-5 with or without IL-1 $(20 \mathrm{ng} / \mathrm{ml})$. $30 \mathrm{~min}$ before cGMP determination, the cells were washed and the media replaced with Earle's BSS containing IBMX (0.1 mM) and either no additions, L-NMMA (30 $\mu \mathrm{M})$, LNMMA and L-arginine ( $300 \mu \mathrm{M})$, or L-NMMA and D-arginine (300 $\mu \mathrm{M})$. Some of the control cells were also treated with SNP $\left(10^{-4} \mathrm{M}\right)$ 5 min before cGMP determination. Values shown are mean \pm SE of eight cultures from four experiments. ${ }^{*} P<0.01$, significantly different from control. ${ }^{+} P<0.025$, significantly different from VSMC treated with IL-1 and no inhibitors.
Figure 4. Effect of inhibitors of soluble guanylate cyclase on IL-1-induced cGMP accumulation in rat VSMC. VSMC were incubated for $24 \mathrm{~h}$ in DME-5 with or without IL-1 $(20 \mathrm{ng} / \mathrm{ml}) .30 \mathrm{~min}$ before cGMP determinations, IBMX $(0.1 \mathrm{mM})$ was added to each of the wells, along with either no additions (CON), LY83583 ( $\left.L Y ; 10^{-5} \mathrm{M}\right)$, methylene blue $\left(M B ; 10^{-5} \mathrm{M}\right)$ or hemoglobin $\left(\mathrm{Hb} ; 10^{-5} \mathrm{M}\right)$. Some of the control cells were also treated with SNP $\left(10^{-4} \mathrm{M}\right) 5 \mathrm{~min}$ before cGMP determination. Values shown are mean $\pm \mathrm{SE}$ of eight cultures from four experiments. ${ }^{*} P<0.001$, significantly different from control. ${ }^{+} P<0.01$, significantly different from VSMC treated with IL-1 and no inhibitors. lene blue (20), and hemoglobin (20), indicate that IL-1 activates soluble guanylate cyclase via a similar mechanism. Methylene blue is thought to inhibit guanylate cyclase directly by oxidation of the hemoprotein moiety which is required for activation (20). Both methylene blue (21) and LY83583 (22) may cause the production of superoxide anions (21) which inactivate endothelium-derived nitric oxide (23). Hemoglobin binds nitric oxide with high affinity (24), and thereby inhibits relaxation and guanylate cyclase activation caused by both endothelium-derived relaxing factor (20) and nitric oxide (5). IL-1-induced activation of cGMP production was reversed by LY83583, methylene blue, and hemoglobin, suggesting that IL-1 activates soluble guanylate cyclase by causing production of nitric oxide.

Recent evidence indicates that nitric oxide is produced enzymatically from the guanidino nitrogen of L-arginine (5-7). L-NMMA, an L-arginine analogue with a methylated guanidino nitrogen (11), blocks endothelial-dependent vasodilatation (7) and production of nitric oxide in endothelial cells (6), presumably by competing with L-arginine for binding to the enzyme, nitric oxide synthase. L-NMMA attenuated IL-1-induced increases in CGMP in rat VSMC, suggesting that IL-1 induces a similar enzymatic pathway of nitric oxide production from L-arginine within VSMC. The effect of L-NMMA was specific in that it was reversed by a 10 -fold excess of $L$-arginine but not by D-arginine, and L-NMMA did not attenuate SNPstimulated cGMP, indicating that L-NMMA does not directly inhibit soluble guanylate cyclase or have nonspecific deleterious effects on the cells.

To assess whether VSMC produce nitric oxide, we determined whether IL-1-treated VSMC release nitrite, a stable oxidation product of nitric oxide. Cytokines induce prolonged production of nitric oxide in macrophages (11), and the nitric oxide is converted to nitrite which accumulates extracellularly (9, 25 ). In the present study, IL-1 induced nitrite accumulation in the media of VSMC incubated in L-arginine-replete tissue culture medium. Both IL-1-induced nitrite release and cGMP accumulation were attenuated in VSMC incubated in L-arginine-deficient medium for $24 \mathrm{~h}$. Repletion of L-arginine 15 min before cGMP measurements in VSMC incubated with IL- 1 in the absence of $\mathrm{L}$-arginine, restored the stimulatory effect of IL-1 on cGMP. These studies directly support our hypothesis that IL-1 induces L-arginine-dependent nitric oxide production in VSMC. 


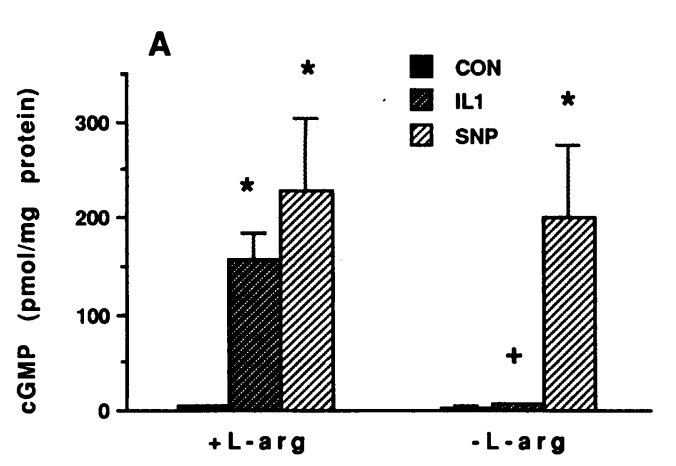

Experiments with short-term depletion of L-arginine suggest that IL-1-induced cGMP accumulation is largely dependent on an extracellular source of $\mathrm{L}$-arginine. The increment in cGMP caused by IL- 1 was attenuated by $80 \%$ when IL-1treated cells were incubated for $4 \mathrm{~h}$ in the absence of $\mathrm{L}$-arginine. The magnitude by which L-arginine depletion attenuates IL-1 induced cGMP accumulation suggests that $L$-arginine availability may be more rate-limiting in cytokine-activated VSMC than in endothelial cells activated with endothelium-dependent vasodilators. Intact blood vessels respond to endotheliumdependent vasodilators even when studied in vitro for many hours in the absence of $\mathrm{L}$-arginine, and L-arginine augments endothelium-dependent relaxation only when endothelial stores of $\mathrm{L}$-arginine are depleted by prolonged or repeated treatment with endothelium-dependent vasodilators (26). Similarly, in cultured endothelial cells, L-arginine enhances brady-
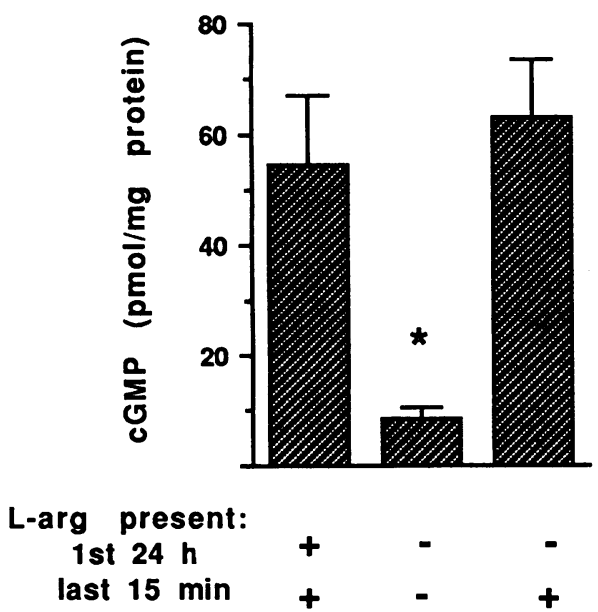

Figure 7. Effect of $\mathrm{L}$-arginine repletion on intracellular CGMP content of VSMC incubated for $24 \mathrm{~h}$ with IL- 1 and without $\mathrm{L}$-arginine. VSMC were incubated in MEM with or without $\mathrm{L}$-arginine, with $5 \%$ dialyzed FCS, antibiotics and IL-1 $(20 \mathrm{ng} / \mathrm{ml})$ for $24 \mathrm{~h}$. L-Arginine $(600 \mu \mathrm{M})$ was replenished in the supernatant of some of the wells $15 \mathrm{~min}$ before obtaining cell extracts for cGMP determination. IBMX $(0.1 \mathrm{mM})$ was added to each of the wells $30 \mathrm{~min}$ before cGMP determinations. Values shown are mean \pm SD of four cultures. ${ }^{*} P<0.005$, significantly different from VSMC incubated $24 \mathrm{~h}$ with $\mathrm{L}$-arginine.
Figure 6. Effect of L-arginine depletion on $(A)$ intracellular cGMP accumulation and $(B)$ extracellular nitrite accumulation in IL-1-treated VSMC. VSMC were incubated in MEM with or without L-arginine, with $5 \%$ dialyzed FCS and antibiotics, and with or without IL-1 $(20 \mathrm{ng} / \mathrm{ml})$ for $24 \mathrm{~h}$. IBMX $(0.1$ $\mathrm{mM}$ ) was added to each of the wells 30 min before cGMP determinations. Values shown are mean $\pm \mathrm{SE}$ of 12 cultures from three experiments. ${ }^{*} P<0.02$, significantly different from control. ${ }^{+} P<0.001$, significantly different from VSMC incubated with IL-1 and L-arginine. kinin-induced nitric oxide release twofold, but only after $24 \mathrm{~h}$ of $\mathrm{L}$-arginine depletion $(6,8)$. These differences may be due to the high turnover of $\mathrm{L}$-arginine in cytokine-activated VSMC where activation is maintained for many hours. In this regard, the fungistatic and cytotoxic actions of macrophages, which are mediated by prolonged production of nitric oxide, have also been shown to be highly dependent on extracellular L-arginine (27).

These studies suggest that IL-1 acts in a fashion similar to endothelium-dependent vasodilators, by activating nitric oxide synthase. However, there are several distinctions between the action of endothelium-dependent vasodilators and that of IL-1. IL-1 acts on an enzyme in vascular smooth muscle, and the effect is delayed and prolonged, whereas endothelium-dependent vasodilators induce a prompt and transient activation of nitric oxide synthase within the endothelium $(6,8)$. Nitric oxide synthase has been proposed to constitute a family of enzymes, consisting of at least two distinct types (28), which are present in many different cell types including endothelial cells (5-8), macrophages (9-11), adrenal cortex (29), brain (30), and neutrophils (31). Type II, originally described in endothelial cells, is a calcium and calmodulin-dependent enzyme, which is rapidly activated by ligand-receptor events at the cell surface (28). In contrast, type I, originally described in macrophages is calmodulin-independent, requires tetrahydrobiopterin as a cofactor, is slowly induced by cytokines and by endotoxin, and remains activated for many hours $(9,11,25,28)$. IL-1 appears to activate type I or macrophage-type nitric oxide synthase in VSMC, since it is induced by a cytokine and by endotoxin (2), and the induction occurs over many hours. Furthermore, whereas endothelium-dependent vasodilators increase nitric oxide production by increasing cytosolic calcium (4), both IL1 -induced inhibition of contraction in aortic rings (1) and IL1 -induced stimulation of CGMP in VSMC are dependent on protein synthesis. The delayed activation of nitric oxide synthase activity in VSMC caused by IL-1 may reflect a requirement for synthesis of an intermediary protein, such as an activator of type I nitric oxide synthase. Alternatively, IL-1 may induce the synthesis of type I nitric oxide synthase itself.

Although nitric oxide produced within endothelial cells acts as an intercellular messenger, modulating smooth muscle tone, our findings suggest that nitric oxide can also be produced within VSMC and act as an intracellular modulator of vascular 

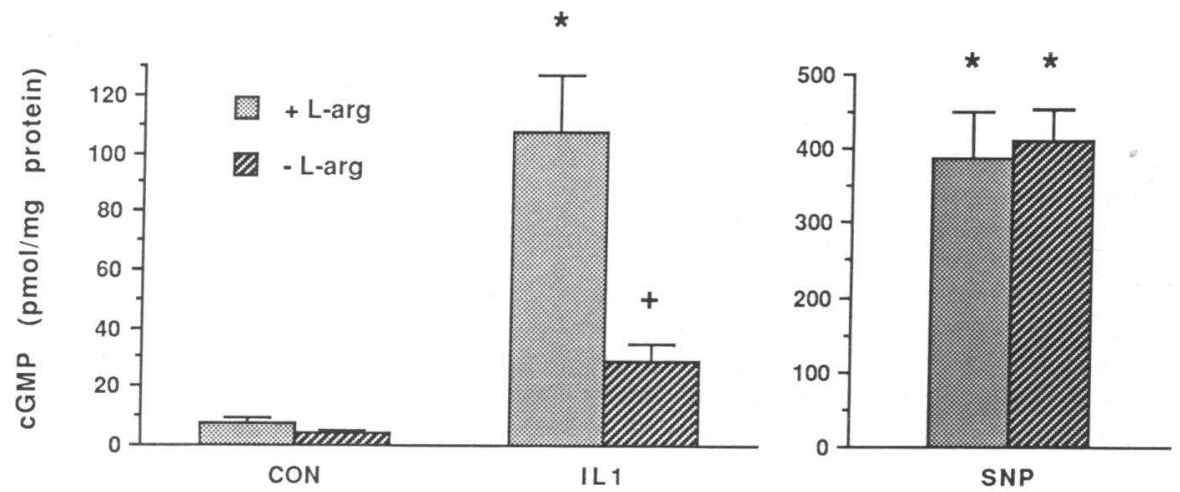

SNP
Figure 8. Effect of 4-h L-arginine depletion on IL-1-induced cGMP accumulation. VSMC were incubated for $20 \mathrm{~h}$ in DME-5 with or without IL-1 $(20 \mathrm{ng} / \mathrm{ml})$. The cells were then washed with BSS and the media replaced with either MEM with $600 \mu \mathrm{M}$ L-arginine ( $+L-a r g)$ or MEM without Larginine (-L-arg). The MEM also contained IBMX $(0.1 \mathrm{mM})$ with or without IL-1. Some of the control cells were treated with SNP $\left(10^{-4} \mathrm{M}\right) 5 \mathrm{~min}$ before cGMP determination. Values shown are mean $\pm \mathrm{SE}$ of eight cultures from four experiments. ${ }^{*} P<0.0025$, significantly different from control. ${ }^{+} P<0.0025$, significantly different from VSMC incubated with IL-1 and Larginine. contraction. In studies of endothelium-dependent vasodilators, extracellular hemoglobin probably blocks relaxation by binding nitric oxide which is released from the endothelium, thereby preventing it from reaching the smooth muscle. In the present study, it is likely that hemoglobin acts as an extracellular sink for nitric oxide, thereby lowering intracellular levels of nitric oxide by enhancing diffusion out of the cell.

We have recently shown that IL-1 induces a time-dependent inhibition of vascular contraction in intact rat aortic rings (1). Like its effects in cultured VSMC, IL-1-induced inhibition of contraction in rat aorta was associated with increases in cGMP, reversed by soluble guanylate cyclase inhibitors (LY83583, hemoglobin, and methylene blue), and was endothelium independent $(1,2)$. The present results demonstrate that IL- 1 acts on isolated VSMC, and together with our previous findings, support the hypothesis that IL-1 induces vasodilatation by L-arginine-dependent production of nitric oxide and activation of soluble guanylate cyclase in vascular smooth muscle cells.

Our studies suggest that nitric oxide production within blood vessels is not restricted to endothelial cells. The IL-1-induced increase in cGMP in VSMC is maintained for many hours, in contrast to the prompt and transient increases caused by endothelium-dependent vasodilators. IL-1-induced production of nitric oxide may contribute to vasodilatation at sites of local infection, to systemic hypotension during sepsis, or to long-term modulation of vascular tone.

\section{Acknowledgments}

The authors gratefully acknowledge Michelle Eldridge for technical assistance and Dr. Jeffrey B. Tatro for critical review of the manuscript.

This work was supported by grants from American Heart Association, Massachusetts Affiliate, Inc. (no. 13-522-889 [DB]); Baxter Healthcare Corporation, Renal Division, Extramural Grant Program (DB); National Institutes of Health grants DK-35930 (BMB) and 5-P50-HL-18318 (JHS).

\section{References}

1. Beasley, D., R. A. Cohen, and N. G. Levinsky. 1989. Interleukin-1 inhibits contraction of vascular smooth muscle. J. Clin. Invest. 83:331-335.

2. Beasley, D. 1990. Interleukin-1 and endotoxin activate soluble guanylate cyclase in vascular smooth muscle. Am. J. Physiol. (Regul. Integrative Comp. Physiol.). 259: R38-R44.

3. Furchgott, R. F. 1984. The role of endothelium in the responses of vascular smooth muscle to drugs. Annu. Rev. Pharmacol. Toxicol. 24:175-197.

4. Ignarro, L. J. 1989. Endothelium-derived nitric oxide: actions and properties. FASEB (Fed. Am. Soc. Exp. Biol.) J. 3:31-36.

5. Palmer, R. M. J., A. G. Ferrige, and S. Moncada. 1987. Nitric oxide release accounts for the biological activity of endothelium-derived relaxing factor. $\mathrm{Na}$ ture (Lond.). 327:524-526.

6. Palmer, R. M. J., D. S. Ashton and S. Moncada. 1988. Vascular endothelial cells synthesize nitric oxide from L-arginine. Nature (Lond.). 333:644-646.

7. Sakuma, I., D. J. Stuehr, S. S. Gross, C. Nathan, and R. Levi. 1988. Identification of arginine as a precursor of endothelium-derived relaxing factor. Proc. Natl. Acad. Sci. USA. 85:8664-8667.

8. Palmer, R. M. J., D. D. Rees, D. S. Ashton, and S. Moncado. 1988. L-arginine is the physiological precursor for the formation of nitric oxide in endothelium-dependent relaxation. Biochem. Biophys. Res. Commun. 153:1251-1256.

9. Ding, A. H., C. F. Nathan, and D. J. Stuehr. 1988. Release of reactive nitrogen intermediates and reactive oxygen intermediates from mouse peritoneal macrophages: comparison of activating cytokines and evidence for independent production. J. Immunol. 141:2407-2412.

10. Hibbs, J. B., R. R. Taintor, and Z. Vavrin. 1987. Macrophage cytotoxicity: role for L-arginine deiminase and imino nitrogen oxidation to nitrite. Science (Wash. DC). 235:473-476.

11. Marletta, M. A., P. S. Yoon, R. Iyengar, C. D. Leaf, and J. S. Wishnok. 1988. Macrophage oxidation of $\mathrm{L}$-arginine to nitrite and nitrate: nitric oxide is an intermediate. Biochemistry. 27:8706-8711.

12. Brock, R. A., R. W. Alexander, L. S. Ekstein, W. J. Atkinson, and M. A. Gimbrone, Jr. 1985. Angiotensin increases cytosolic free calcium in cultured vascular smooth muscle cells. Hypertension. 7:I105-I109.

13. Gunther, S., R. W. Alexander, W. J. Atkinson, and M. A. Gimbrone, Jr. 1982. Functional angiotensin II receptors in cultured vascular smooth muscle cells. J. Cell Biol. 92:289-298.

14. Brown, M. S., and J. L. Goldstein. 1983. Lipoprotein metabolism in the macrophage: implications for cholesterol disposition in atherosclerosis. Annu. Rev. Biochem. 52:223-261.

15. Stein, O., and Y. Stein. 1980. Bovine aortic endothelial cells display macrophage-like properties towards acetylated [I-125]-labelled low density lipoprotein. Biochem. Biophys. Acta. 620:631-635.

16. Green, L. C., D. A. Wagner, J. Glogowski, P. L. Skipper, J. S. Wishnok, and S. R. Tannebaum. 1982. Analysis of nitrate, nitrite and $\left[{ }^{15} \mathrm{~N}\right]$ nitrate in biological fluids. Anal. Biochem. 126:131-138.

17. Hedlund, B. E., and R. M. Condie. Biochemical and physiological aspects of a hemoglobin based blood substitute. In The Red Cell; Sixth Ann Arbor Conference. Prog. Biol. Clin. Res. 165:159-178.

18. Myers, P. R., R. L. Minor, R Guerra, J N Bates, and D. G. Harrison. 1990. Vasorelaxant properties of endothelium-derived relaxing factor more closely resemble S-nitrosocysteine than nitric oxide. Nature (Lond.). 345:161163.

19. Diamond, J. 1987. Effects of LY83583, nordihydroguairetic acid, and quinacrine on cyclic GMP elevation and inhibition of tension by muscarinic agonists in rabbit aorta and left atrium. Can. J. Physiol. Pharmacol. 65:19131917.

20. Martin, W., G. M. Villani, D. Jothianandan, and R. F. Furchgott. 1985. Selective blockade of endothelium-dependent and glyceryl trinitrate-induced re- 
laxation by hemoglobin and by methylene blue in the rabbit aorta. J. Pharmacol. Exp. Ther. 232:708-716.

21. McCord, J. M., and I. Fridovich 1970. The utility of superoxide dismutase in studying free radical reactions. J. Biol. Chem. 245:1374-1377.

22. Mulsch, A., A. Luckhoff, U. Pohl, R. Busse, and E. Bassenge. 1989. LY 83583 (6-anilino-5,8-quinolinedione) blocks nitrovasodilator-induced cyclic GMP increases and inhibition of platelet activation. Naunyn-Schmiedberg's. Arch. Pharmacol. 340:119-125.

23. Rubanyi, G. M., and P. M. Vanhoutte. 1986. Superoxide anions and hyperoxia inactivate endothelium-derived relaxing factor. Am. J. Physiol. (Heart Circ. Physiol.). 250:H822-H827.

24. Gibson, Q. H., and F. J. W. Roughton. 1957. The kinetics and equilibria of the reactions of nitric oxide with sheep haemoglobin. J. Physiol. (Lond.). 136:507-526.

25. Stuehr, D. J., and M. A. Marletta. 1985. Mammalian nitrate biosynthesis. Mouse macrophages produce nitrite and nitrate in response to Escherichia coli lipopolysaccharide. Proc. Natl. Acad. Sci. USA. 82:7738-7742.

26. Gold, M. E., P. A. Bush, and L. J. Ignarro. 1989. Depletion of arterial l-arginine causes reversible tolerance to endothelium-dependent relaxation. Biochem. Biophys. Res. Commun. 164:714-721.

27. Granger, D. L., J. B. Hibbs, Jr., J. R. Perfect, and D. T. Durack. 1988 Specific amino acid (L-arginine) requirement for the microbiostatic activity of murine macrophages. J. Clin. Invest. 81:1129-1136.

28. Nathan, C. F., and D. J. Stuehr. 1990. Does endothelium-derived nitric oxide have a role in cytokine-induced hypotension? J. Natl. Cancer Inst. 82:726728.

29. Palacios, R. G. Knowles, R. M. J. Palmer, and S. Moncada. 1989. Nitric oxide from $\mathrm{L}$-arginine stimulates the soluble guanylate cyclase in adrenal glands. Biochem. Biophys. Res. Commun. 165:802-809.

30. Schmidt, H. H. H. W., P. Wilke, B. Evers, and E. Bohme. 1989. Enzymatic formation of nitrogen oxides from $\mathrm{L}$-arginine in bovine brain cytosol. Biochem. Biophys. Res. Commun. 165:284-291.

31. McCall, T. B., N. K. Boughton-Smith, R. M. J. Palmer, B. J. R. Whittle, and S. Moncada. 1989. Synthesis of nitric oxide from L-arginine by neutrophils: release and interaction with superoxide anion. Biochem. J. 261:293-296. 